๑ e ISSN-0976-6855 | Visit us : www.researchjournal.co.in

\title{
Development and genetic analysis of inter sub specific Recombinant Inbred Line population in blackgram (Vigna mungo (L.) Hepper)
}

R. VINOTH AND P. JAYAMANI*

Department of Pulses, Centre for Plant Breeding and Genetics, Tamil Nadu Agricultural University, COIMBATORE (T.N.) INDIA

\section{ARITCLE INFO}

Received : 02.02 .2016

Revised : 05.03.2016

Accepted : 14.03.2016

\section{KEY WORDS :}

Blackgram, Mapping population, Frequency distribution, Biometrical traits, Transgressive segregation
*Corresponding author:

Email: jayamani1108@gmail.com

\begin{abstract}
Blackgram (Vigna mungo) is fourth important pulse crop of India. Major constraints in achieving higher yield of blackgram are absence of suitable ideotypes for different cropping systems, poor harvest index and susceptibility to pests and diseases. Genetic maps can be constructed based on mapping population. Among the mapping populations, Recombinant Inbred Lines (RIL) is more advantages than others. In the present study, an inter sub specific RIL population was developed by crossing VBN $(\mathrm{Bg})$ 4 x Vigna mungo var. silvestris $22 / 2$ by single seed decent method. A total of 195 RILs were evaluated for 11 biometrical traits. RIL 113 recorded the highest mean for single plant yield $(9.90 \mathrm{~g})$ along with more number of pods plant (42.84). RIL 125 recorded the maximum yield of $8.93 \mathrm{~g}$ per plant along with more number of clusters per plant (17.50) and RIL 131 had single plant yield of $7.99 \mathrm{~g}$ along with more number of pods per plant (34.00). RILs with high yield and yield attributing traits can be used to develop high yielding varieties. RILs isolated with specific traits could be used as pre breeding material for the improvement of blackgram.
\end{abstract}

How to view point the article : Vinoth, R. and Jayamani, P. (2016). Development and genetic analysis of inter sub specific Recombinant Inbred Line population in blackgram (Vigna mungo (L.) Hepper). Internat. J. Plant Protec., 9(1) : 237-245. 